Inna Levina,

PhD (Candidate of Pedagogical Sciences), associate professor, Department of Pedagogy, South Ukrainian National Pedagogical University named after $K$. D. Ushynsky, 26, Staroportofrankivska, Odesa, Ukraine

\title{
THE MODEL OF FUTURE TEACHERS' PROJECT COMPETENCE FORMATION IN THE PROCESS OF PROFESSIONAL TRAINING
}

The article represents the results of theoretical analysis of project competence as a component of future teacher's professional competence. The author reveals the essence and structure of project competence phenomenon, defines the criteria and levels of this competence formation, submits the model of future teachers' project competence formation in the course of professional training in a higher educational institution.

Keywords: model, project, projection, project activity, project competence.

Intrinsic processes and social situation in Ukraine related to the current development of society democratisation raised a range of problems for pedagogical science. Especially noteworthy is the problem of higher pedagogical education modernisation, providing science-based changes in strategies and structure of education in general, the search for new content, methods and forms of education and technologies intended to implementing these changes in the course of future teachers' training, establishment of professionalism in the educational system.

Changes in school education require teachers' abilities to transform, complement and integrate the existing learning material, which, in its turn, is impossible without teacher's project competence. Exactly these circumstances stimulate the awareness of the need for changes in future teachers' professional training.

In the works by famous scientists (V. Bondar, A. Boiko, V. Butenko, I. Ziaziun, V. Hrynev, A. Moroz, O. Pekhota, A. Savchenko, I. Prokopenko, H. Trotsko, H. Shevchenko, M. Yarmachenko), modernisation of pedagogical education is considered as a factor that regularly optimises the process of a teacher's professional training.

The issues of students' professional pedagogical training improvement at higher pedagogical educational institutions were considered by a great number of researchers who distinguished definite groups of professional skills: general pedagogical (A. Abdullina, A. Aleksiuk, Ye. Antonova, I. Bohdanova, V. Vyshkovskyi, A. Dubaseniuk, A. Ostrianskyi, V. Slastenin and others), didactic (N. Bilokur, V. Bondar, A. Bulvinska, P. Husak, I. Ivanchenko, A. Kendiukhova, I. Kolesnikova, H. Muraviova, A. Moroz, I. Shaposhnikov and others), didactic and methodical (N. Voskresenska, N. Maksimenko). Despite the lack of a single classification of future teacher's professional qualities, his/her production functions, components of pedagogical activities, most pedagogues agree on the fact that a teacher's pedagogical activity is based on projective abilities.
The review of the psychological and pedagogical literature has demonstrated that the theory of competencebased approach is reflected in the works by V. Baidenko, N. Bibik, V. Bespalko, Ye. Zeier, I. Zymnia, L. Petrovska, A. Pukhovska, M. Rozov, A. Khutorskoi, and others; the specifics of professional competence formation at higher educational institutions was outlined in research works by N. Briukhanova, T. Volobuieva, T. Ysaeva, R. Hurevych, L. Semenets, L. Tarhan, S. Fedorova and others.

It should be pointed out that scholars do not define a unified approach to the distinguishing of the structural components of professional competence in general and teachers' professional competence in particular. Thus, R. Hurevych distinguished the following fundamental characteristics of professional competence: wealth of knowledge sufficient for efficient work; systematicity of knowledge organisation and structuring, awareness of the real relations between the elements, classification of knowledge, distinguishing the main key elements; relativity of interrelations of the field of knowledge, the ability to update both content and relationships under the influence of objective facts; fundamentality of knowledge, which defines the role of general principles and ideas; methodological character, pragmatism, inseparability of relationships "knowledge-activities"; knowledge reflexivity [3, p. 46]. T. Isaieva identifies the following components in professional competence: adaptivecivilisational; social-organisational; subject-methodical; communicative; axiological [7, p. 17].

In the structure of subject teacher's professional competence L. Semenets distinguishes a number of competences: project, conceptual, axiological-personal, didactic, psychological, managerial and special subjectmatter [15, p. 183-186].

Review of psycho-pedagogical literature has shown that the problem of forming future teachers' project competence requires more detailed consideration.

The purpose of the paper is developing the model of future teachers' project competence formation in the 
course of professional training at a higher educational institution.

The following tasks facilitated achievement of the purpose:

- conducting a theoretical review of the project competence as a component of future teacher's professional competence;

- determining the essence and structure of the "project competence" phenomenon;

- identifying the criteria and levels of the project competence formation;

- defining pedagogical conditions for future teachers' project competence formation.

Research methods: analysis and synthesis of scholarly literature, modeling, pedagogical supervision.

In contemporary pedagogy, projection is correlated both with regulatory procedures of algorithmic nature and with teacher's techniques of creative activity. Especially actively this concept is used by scientists who develop the idea of teaching excellence: V. Slastenin, V. Zahviazynskyi, V. Kan-Kalik, Yu. Lvov and others.

A significant contribution to the development of principles of technological projection was made by A. Uman; his research works covered the didactic category of learning activities. He found that the basis for developing projection methods of learning process (lesson) is the relationship and interaction of the technological characteristics of all didactic categories.

The review of studies, in which learning projection principles are considered from different perspectives, would not be complete without analyzing of Yu. Babanskyi's views, who began to consider the totality of didactic categories from the standpoint of learning process projection. He called this approach "study optimisation”. Yu. Babanskyi considered projection (planning) of the educational process as a series of practical interpretation of the learning objectives, educational content, organisation forms and teaching methods. In his opinion, the optimal teaching plan is the one that unites purpose, content, forms and methods of teaching.

Structural projective component as one of the most significant among the components of professional readiness of a teacher was distinguished by N. Kuzmina: "It (this component) includes actions related to anticipating, "getting ahead" - forecasting the system of consequences of solving the system of tasks during a definite planned period of time" [1, p. 37]. Structural projective abilities are defined as "a system and a sequence of teacher's actions, which is associated with solving pedagogical problems on constructing the object of educational and cognitive activities of a learner, in accordance with the goals of his/her educating" [1, p. 102].

N. Yakovleva defines the project competence of a teacher as a set of knowledge, skills and personal qualities necessary for preparation and implementation pedagogical projects into educational process, which improves the quality of learners' education. In addition, the researcher emphasised that the project competence is not a new for- mation that is developed naturally in the process of becoming a teacher; it is necessary to form it intentionally. Being a part of the professional competence of a teacher, the project competence, according to N. Yakovleva, can be successfully formed under the conditions of the educational process of a higher educational institution [8].

S. Skvortsova considers project competence of a teacher as the capability of teachers to project learning process on the subject during an academic year, to design lessons according to a variety of teaching materials that meet modern requirements, the ability to simulate teacher and learners' activities aimed at achieving educational results at every stage of a lesson.

Thus, teacher' project competence is an integrative professional and personal quality based on knowledge, skills, experience and personal value orientations of a teacher that contributes to effective preparation and implementation of educational projects.

According to research works by V. Bezrukova, I. Kolesnikova, N. Kuzmina, M. Levina, V. Liaudis, Ye. Titova, the following elements in the structure of a teacher's project competence were distinguished: motivation and targeted-oriented, cognitive, operational and reflexively-personal. In accordance with the definition and structure of the project competence, the following criteria (motivational-evaluative, cognitive-active, reflectiveevaluative) and levels (reproductive, productive and creative) of its formation have been identified.

In the context of the requirements of competencebased approach to the educational process, the model of future teachers' project competence in the course of training has been developed.

The developed model is composed of target-oriented, content-related, technological and analytically-productive units. Each block of the model is aimed at the formation of the corresponding component of project competence. The interrelation between them provides the integrity of the competence system as a result of model's functioning in the system of future teachers' professional training. Efficiency of the model's functioning is provided by a number of conditions: targeted formation of students' emotionally positive attitude towards professional activities; regular involvement them into project activities and purposeful formation of project abilities; students' engagement into creative project activities.

Target-oriented unit of the model is represented by the target and the tasks. The main target is the formation of students' project competence in the system of their pedagogical training. The main target is implemented through methodological approaches to the organisation of the process of students' pedagogical training: systemoriented, personal activity, practice-oriented approaches, taking into account the following teaching principles: understandability, combination of theory and practice, activity, systematicity, consistency. 


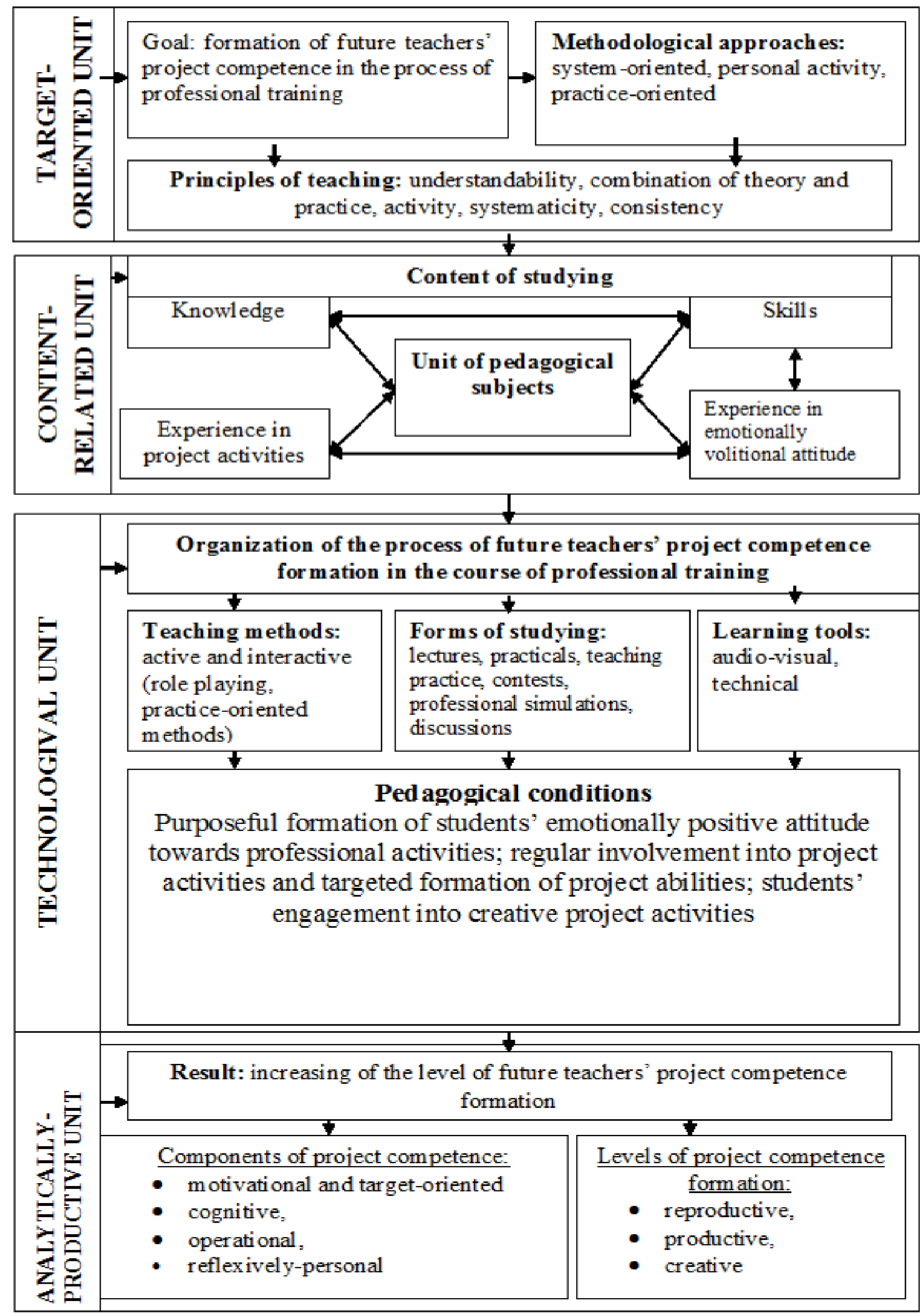

Pic. 1. The model of future teachers' project competence formation in the process of professional training 
Content-related unit of future teachers' project competence formation in the system of their pedagogical training includes knowledge, abilities and skills formed in the process of studying, experience in project activities, experience in emotionally volitional attitude. In addition, content-related unit involves introduction of theoretical background of project activity and its implementation in the educational process to future professionals; identifying theoretical and practical bases of forming various elements of project competence.

Technological unit of the formation of future teachers' project competence in the process of studying pedagogical subjects includes: forms of studying (lectures, practicals, teaching practice, contests, professional simulations, discussions); teaching methods (active and interactive (game methods, simulation of professional activities in the learning process)); learning tools (audio-visual, technical). The main objective of the technological unit is strict organisation of pedagogical training for project activity and purposeful formation of project abilities (ability to design specific learning situations and to choose their optimal solution; the ability to design all the components of the lesson from goal-setting to monitoring and analysis; the ability to design a system of lessons on a particular subject).

Analytically-productive unit involves conducting intermediate and control analytical procedures and assessment of the efficiency of the work performed in the course of interaction between the subjects of educational process. The main task of the unit is defining the characteristics of maturity of the levels of future teachers' pro-

\section{ЛІТЕРАТУРА}

1. Исаева Т. Е. Классификация профессионально-личностных компетенций вузовского преподавателя / Т. Е. Исаева // Труды международной научнопрактической Интернет-конференции «Преподаватель высшей школы в XXI веке». - Сб. 4. - Ростов-н/Д : Рост. гос. ун-т путей сообщения. - 2007. - С. 15-21.

2. Кузьмина Н. В. Профессионализм деятельности преподавателей и мастера производственного обучения профтехучилища / Н. В. Кузьмина. - М. : Высшая школа, 1989. - 167 с.

3. Поздняк С. Н., Кузнецова М. Л. Проблема формирования проектной компетентности учителя географии в процессе методической подготовки / С. Н. Поздняк, М. Л. Кузнецова // Сборник материалов XVI Междунар. науч.-практ. конф. «Обучение и воспитание: методики и практика 2014/15 учебного года» / под общ. ред. С. С. Чернова. - Новосибирск : Изд-во ЦРНС. - 2014. -С. 124-129 .

4. Семенець Л. М. Педагогічна компетентність викладача як умова формування професійної компе-

\section{REFERENCES}

1. Isayeva, T. Ye. (2007). Klassifikatsiya professionalno-lichnostnykh kompetentsyi vuzovskogo ject competence. An integral part of the represented model of project competence formation is personal component, which includes interest, motivation, emotional and volitional regulation, attitude towards project activity, self-evaluation of the degree of project competence formation.

Conclusions.

1. Teacher's project competence is an integrated professional and personal quality based on his/her knowledge, abilities, personal experience and value orientations.

2. The structure of teacher's project competence includes the following components: motivation and targeted-oriented, cognitive, operational and reflexivelypersonal.

3. The developed model of the formation of future teachers' project competence consists of targetoriented, content-related, technological and analyticallyproductive units; each of them is intended to the formation of corresponding component of the abovementioned competence.

4. Efficiency of the proposed model is provided by a number of conditions: the formation of students' emotionally positive attitude towards project activities; regular involvement into project activities and purposeful formation of project abilities; engaging students into creative activities.

Prospects for further researches involve conducting experiment aimed at testing the developed model of the formation of future teachers' project competence.

тентності майбутнього вчителя / Л. М. Семенець // Вісник Житомирського державного університету ім. I. Франка. - 2010. - Вип. 53. - С. 183-186.
5. Скворцова С. О. Проектувальномоделювальна складова методичної компетеності вчителя математики [Електронний ресурс] / C. О. Скворцова. - 2013. - Режим доступу : https://skvor.info/publications/articles/view.html?id=173

6. Уман А. И. Технологический подход к обучению: теоретические основы. Монография / А. И. Уман. - Орел : ОГУ, 1997. - 208 с.

7. Щербатюк Л. Б. Професійна компетентність майбутніх інженерів- механіків - складна динамічна система / Л. Б. Щербатюк, В. М. Щербатюк // Вісник Черкаського університету. Серія Педагогічні науки. 2009. - Вип. 165. - С. 45-49.

8. Яковлева Н. О. Педагогическое проектирование инновационных систем : автореф. дис. на соискание степени д-ра пед. наук. - Челябинск, 2003. - 35 с.

prepodavatelya [Classification of professional and personal competencies of academic lecturers]. 
Prepodavatel vysshey shkoly $v$ XXI veke - University lecturer in the XXI century: proceeding of International research and practice Internet-conference, 4, 15-21. Rostov-on-Don [in Russian].

2. Kuzmina, N. V. (1989). Professionalizm deyatelnosti prepodavateley i mastera proizvodstvennogo obucheniya proftekhuchilischa [Professionalism of teachers and masters of vocational training at vocational school]. Moscow: Vysshaya shkola [in Russian].

3. Pozdnyak, S. N., \& Kuznetsova, M. L. (2014). Problema formirovaniya proektnoy kompetentnosti uchitelya geografii v protsesse metodicheskoy podgotovki [The problem of the formation of geography teachers' project competence in the process of instructional training]. Obucheniye $i$ vospitaniye: metodiki $i$ praktika Education and upbringing: methods and practice: Proceedings of XVI International research and practice conference. S.S. Chernov (Ed.). (p. 124-129). Novosibirsk [in Russian].

4. Semenets, L. M. (2010). Pedahohichna kompetentnist vykladacha yak umova formuvannia profesiinoi kompetentnosti maibutnoho vchytelia [Pedagogical competence of a teacher as condition for future teacher's professional competence formation]. Visnyk Zhytomyrskoho derzhavnoho universytetu im. I. Franka - Bulletin of
Zhytomyr State University named after I. Franko, 53, 183-186 [in Ukrainian].

5. Skvortsova, S. O. (2013). Proektuvalnomodeliuvalna skladova metodychnoi kompetenosti vchytelia matematyky [Projective and modeling component of methodic competence of a mathematics teacher]. Retrieved from: https://skvor.info/publications/articles/view.html?id=173 [in Ukrainian].

6. Uman, A. I. (1997). Tekhnolohycheskiy podkhod k obucheniyu: teoreticheskiye osnovy [Technological approach to teaching: theoretical background]. Orel: OGU [in Russian].

7. Shcherbatiuk, L. B. (2009). Profesiina kompetentnist maibutnikh inzheneriv- mekhanikiv - skladna dynamichna systema [Professional competence of future mechanic engineers - complicated dynamic system]. Visnyk Cherkaskoho universytetu. Seriia: Pedahohichni nauky Bulletin of Cherkasy University. Series: Educational sciences, 145, 45-49 [in Ukrainian].

8. Yakovleva, N. O. (2003). Pedagogicheskoye proektirovaniye innovatsionnykh sistem [Pedagogical design of innovative systems]. Extended abstract of candidate's thesis. Chelyabinsk [in Russian].

\section{Инна Анатольевна Левина, кандидат педагогических наук, доиент кафедры педагогики, Южноукраинский национальный педагогический университет имени К. Д.Ушинского, ул. Старопортофранковская, 26, г. Одесса, Украина}

\section{МОДЕЛЬ ФОРМИРОВАНИЯ ПРОЕКТНОЙ КОМПЕТЕНТНОСТИ БУДУЩИХ УЧИТЕЛЕЙ В ПРОЦЕССЕ ПРОФЕССИОНАЛЬНОЙ ПОДГОТОВКИ}

В статье представлены результаты теоретического анализа проектной компетентности как составляющей профессиональной компетентности будущего учителя. Автор выявляет сущность и структуру феномена «проектная компетентность», определяет критерии и уровни сформированности этой компетентности, представляет модель формирования проектной компетентности будущих учителей в процессе профессиональной подготовки в ВУЗе. Проектная компетентность учителя представляет собой интегративное профессионально-личностное качество, основанное на знаниях, умениях, личностном опыте и ценностных ориентациях учителя, способствующих эффективной подготовке и внедрению образовательных проектов. В структуре проектной компетентности учителя выделяем следующие компоненты: мотивационно-целевой, когнитивный, операциональный и рефлексивно-личностный. В соответствии с определением и структурой проектной компетентности, были выявлены критерии (мотивационно-ценностный, когнитивно-деятельностный и рефлексивно-оценочный) и уровни её сформированности (репродуктивный, продуктивный и креативный). С учетом требований компетентностного подхода к образовательному процессу была разработана модель формирования проектной компетентности будущих учителей в процессе профессиональной подготовки. Разработанная модель является совокупностью составляющих ее целевого, содержательного, технологического и аналитико-результативного блоков. Каждый блок модели нацелен на формирование соответствующего компонента проектной компетентности. Взаимосвязи между ними обеспечивают системную целостность компетентности как результат функционирования модели в системе профессиональной подготовки будущих учителей. Продуктивность функционирования модели обеспечивается соблюдением ряда условий: формирование у студентов эмоционально-положительного отношения к проектной деятельности; систематическое включение их в проектную деятельность и целенаправленное формирование проектных умений; привлечение студентов к креативной проектной деятельности. Неотъемлемой частью представленной модели формирования проектной компетентности является личностный компонент, который включает интерес, мотивацию, эмоционально-волевую регуляцию, отношение к проектной деятельности, самооценку степени сформированности проектной компетентности.

Ключевые слова: модель, проект, проектирование, проектная деятельность, проектная компетентность. 
Інна Анатоліївна Левіна, кандидат педагогічних наук, дочент кафедри педагогіки, Південноукраӥнський національний педагогічний університет імені К. Д. Уиинського, вул. Старопортофранківська, 26, м. Одеса, Украӥна

\section{МОДЕЛЬ ФОРМУВАННЯ ПРОЕКТНОЇ КОМПЕТЕНТНОСТІ МАЙБУТНІХ УЧИТЕЛІВ У ПРОЦЕСІ ПРОФЕСІЙНОЇ ПІДГОТОВКИ}

У статті представлено результати теоретичного аналізу проектної компетентності як складової професійної компетентності майбутнього вчителя. Автором виявлено сутність і структуру феномена «проектна компетентність», визначено критерії та рівні сформованості цієї компетентності, розроблено модель формування проектної компетентності майбутніх учителів у процесі професійної підготовки в ВНЗ. Проектна компетентність учителя являє собою інтегративну професійно-особистісну якість, що заснована на знаннях, уміннях, особистісному досвіді і ціннісних орієнтаціях учителя, які сприяють ефективній підготовці та впровадженню освітніх проектів. У структурі проектної компетентності вчителя виділено такі компоненти: мотіваційно-цільовий, когнітивний, операційний та рефлексивноособистісний. Відповідно до визначення і структури проектної компетентності, було виявлено критерії (мотиваційно-ціннісний, когнітивно-діяльнісний і рефлексивно-оцінний) та рівні їі сформованості (репродуктивний, продуктивний і креативний). 3 урахуванням вимог компетентнісного підходу до освітнього процесу була розроблена модель формування проектної компетентності майбутніх учителів у процесі професійної підготовки. Розроблена модель $\epsilon$ сукупністю складових іiї цільового, змістового, технологічного і аналітико-результативного блоків. Кожен блок моделі націлений на формування відповідного компонента проектної компетентності. Взаємозв'язок між ними забезпечує системну цілісність компетентності як результату функціонування моделі в системі професійної підготовки майбутніх учителів. Продуктивність функціонування моделі забезпечується дотриманням ряду умов: формування у студентів емоційно-позитивного ставлення до професійної діяльності; систематичне включення їх у проектну діяльність і цілеспрямоване формування проектних вмінь; залучення студентів до креативної проектної діяльності. Невід'ємною частиною представленої моделі формування проектної компетентності є особистісний компонент, який включає інтерес, мотивацію, емоційно-вольову регуляцію, ставлення до проектної діяльності, самооцінку ступеня сформованості проектної компетентності.

Ключові слова: модель, проект, проектування, проектна діяльність, проектна компетентність.

Рецензент: д. пед. н., проф. І. В. Бужина

Подано до редакиії 06.10.2016

УДК: $371.15+06.053 .56+372.461+811.581$

Олександра Володимирівна Попова, кандидат педагогічних наук, дочент кафедри перекладу і теоретичної та прикладної лінгвістики, Південноукраїнський національний педагогічний університет імені К. Д. Уиинського, вул. Старопортофранківська, 34, м. Одеса, Украӥна

\section{МІЖНАРОДНИЙ ПРОЕКТ «ІНСТИТУТ КОНФУЦІЯ» ЯК ОСВІТНЬО- ВИХОВНА ДЕТЕРМІНАНТА КОНЦЕПЦІЇ ФОРМУВАННЯ ПРОФЕСІЙНОӤ КОМПЕТЕНТНОСТІ МАЙБУТНІХ ПЕРЕКЛАДАЧІВ КИТАЙСЬКОӤ МОВИ}

У статті досліджено проблему змісту позааудиторної роботи в системі професійно-мовленнєвої підготовки майбутніх перекладачів китайської мови в закладах вищої освіти. У роботі проаналізовано сутність освітньо-виховної компоненти в контексті реалізації Міжнародного проекту «Інститут Конфуція»; наведено приклади освітньо-культурних заходів, щзо уможливлюють продуктивність формування професійної компетентності майбутніх перекладачів китайської мови в умовах університетської освіти України.

Ключові слова: професійно-мовленнєва підготовка, перекладачі китайської мови, позааудиторна робота, Інститут Конфучія, професійна компетентність, освітньо-культурні заходи, університетська освіта.

Теоретичні та практичні дослідження ефективних засобів, форм і методів реалізації позааудиторної роботи в системі професійної підготовки майбутніх фахівців у закладах вищої освіти підтверджують нагальну потребу у визначенні та обгрунтуванні освітньо-виховних детермінант, що уможливлюють успішне поєднання аудиторної та не-аудиторної складових професійно-мовленнєвої підготовки майбутніх перекладачів-сходознавців.
Значне місце в системі університетської освіти посідає розв'язання проблеми, що виникає у результаті розбіжностей між пріоритетами в галузях науки й освіти країн-учасників міжнародних проектів і специфікою навчально-вихованого процесу у конкретному вищому навчальному закладі України. Ця проблема зумовлює мету статті - вивчити зміст позааудиторної роботи в системі професійномовленнєвої підготовки майбутніх перекладачів 